\title{
CONGRESS AS CULPRIT: HOW LAWMAKERS SPURRED ON THE COURT'S ANTI-CONGRESS CRUSADE
}

\author{
NEAL DEVINS $\dagger$
}

\section{INTRODUCTION}

Poor Congress. Twenty-seven of its laws have been struck down in just over six years. ${ }^{1}$ According to the New York Times, Congress is now "The High Court's Target." And to law professors, the Court is increasingly "obliterating a role for Congress as a separate institution" - so much so that examining the "Causes of the Recent Turn in Constitutional Interpretation" and sorting out whether it is time to

Copyright (C) 2001 by Neal Devins.

$\dagger$ Goodrich Professor of Law and Professor of Government, College of William and Mary. This Essay is a response to Christopher H. Schroeder, Causes of the Recent Turn in Constitutional Interpretation, 51 DUKE L.J. 307 (2001), presented at the Constitution in Exile conference hosted by the Program in Public Law at Duke University School of Law on October 57, 2000. Thanks to Chris Schroeder for inviting me to the conference, to Michael Dry and Adina Dziuk for helping me research this Essay, and to Lou Fisher, Bob Nagel, Suzanna Sherry, Bill Treanor, and Keith Whittington for helpful comments.

1. From April 1995 to June 2000, the Court declared unconstitutional twenty-three federal statutes. Stuart Taylor, Jr., The Tipping Point, 32 NAT'L J. 1810, 1811 (2000). In its 2001 Term, the Court invalidated all or part of four federal statutes. Linda Greenhouse, In the Year of Florida Vote, Supreme Court Also Did Much Other Work, N.Y. TIMES, July 2, 2001, at A12.

2. Linda Greenhouse, The High Court's Target: Congress, N.Y. TIMES, Feb. 25, 2001, 4, at 3 .

3. Id. (quoting Robert Post, Alexander F. and May T. Morrison Professor of Law, University of California, Berkeley School of Law); see also Christopher Bryant \& Timothy J. Simeone, Remanding to Congress: The Supreme Court's New "On the Record" Constitutional Review of Federal Statutes, 86 CoRnell L. REv. 328, 332-354, 369-388 (2001) (noting the Supreme Court's increased scrutiny of legislative records in its recent rulings on the constitutionality of federal statutes, and concluding, ultimately, that this approach is an unwarranted intrusion into the congressional sphere); Larry Kramer, The Arrogance of the Court, WASH. PosT, May 23, 2000, at A29 (arguing that the Rehnquist Court's overturning of the Violence Against Women Act is indicative of the Supreme Court's recent tendency to interfere with the legislative process). 
bring the "Constitution in Exile" in from the cold seem anything but academic exercises. ${ }^{4}$

Notwithstanding this hue and cry, Congress seems a bit oblivious to its fate. Although the Democratically controlled Senate Judiciary Committee may soon take recent Supreme Court decisionmaking into account when confirming President George W. Bush's judicial nominees, Congress has yet to strike back at the Court in any meaningful way. Indeed, rather than condemn the Court and launch a counteroffensive, Congress has paid little notice to the Court's decisionmaking. If anything, as I will argue in this Essay, Congress had been (and still may be) spurring the Court into action by signaling its indifference to the constitutional fate of its handiwork. First, Congress, through word and deed, increasingly treats the Court as if it is the ultimate interpreter of the Constitution. Second, unless responding to a Supreme Court decision invalidating federal legislation, Congress has shown little interest in taking Court rulings into account when crafting constitutionally problematic laws. Third, by slowing down the confirmation process, by failing to increase the salaries of federal judges, and by disregarding calls to limit federal court litigation to matters that are truly national, Congress has made the job of being a federal judge less desirable.

For all these reasons, the Court has had little incentive to accommodate Congress and, if anything, it may see the invalidation of some federal statutes as a way both to assert its own power and to pay Congress back for its insensitive management of the courts. Furthermore, there has been little reason for the Justices to fear reprisal. Congress's rhetoric emphasizes the supremacy of the Court's interpretation of the Constitution. Moreover, the Justices' invalidation of federal statutes has left intact analogous state programs and, for the most part, allowed Congress to revisit issues by recrafting the invalidated statutes.

In calling attention to how Congress's attitudes toward both the Court and the Constitution may have factored into the Court's decisionmaking, I see my project as complementing Christopher Schroeder's examination of recent decisions invalidating federal statutes. ${ }^{5}$

4. I refer here, of course, to this conference, especially Christopher H. Schroeder, Causes of the Recent Turn in Constitutional Interpretation, 51 DUKE L.J. 307 (2001). See also William W. Van Alstyne, Foreword: The Constitution in Exile: Is It Time to Bring It in from the Cold?, 51 DUKE L.J. 1 (2001).

5. See generally Schroeder, supra note 4 (suggesting that the Rehnquist Court's federalism opinions are motivated by a distrust of the federal government). 
Specifically, just as the social norm of distrust in the federal government affects the Court's understanding of the deference it owes Congress, ${ }^{6}$ the Court is likewise affected by its "inside the Washington, D.C., beltway" impressions of Congress.

Before turning to my examination of Congress's role in precipitating the current constitutional moment, ${ }^{7}$ I think it useful to take note of how the 1930s Congress-through sloppy legislative drafting-prompted some of the Court's anti-New Deal activism. In other words, to the extent that today's Congress is fueling a return to the "exiled" pre-New Deal Constitution, the past is certainly prologue.

\section{LESSONS FROM THE 1937 CONSTITUTIONAL REVOLUTION}

Congress played an instrumental role both in prompting the Court to repudiate several early New Deal statutes and in facilitating the Court's subsequent embrace of the New Deal. ${ }^{8}$ Consider, for example, two statutes invalidated by the Court-the Railroad Retirement Act of $1934^{\circ}$ and the Frazier-Lemke Farm Debt Relief Act of 1934. ${ }^{10}$ Congress, when enacting the Retirement Act, "whipped the legislation through," with the House "consider[ing] it for only forty

6. Id. at 351-59.

7. See infra notes $25-116$ and accompanying text (assessing Congress's responsibility for the Supreme Court's willingness to overturn legislation); see also Schroeder, supra note 4, at 315-22 (summarizing Bruce Ackerman's theory of constitutional moments).

8. I make this point in Neal Devins, Government Lawyers and the New Deal, 96 Colum. L. REV. 237, 250-61 (1996). For a more comprehensive (but somewhat different) treatment of this subject, see BARRY CUSHMAN, RETHINKING THE NEW DEAL COURT: THE STRUCTURE OF A Constitutional REvolution 9-47 (1998) [hereinafter Cushman, RETHINKING THE NeW DEAL COURT] (approaching changes in the constitutional jurisprudence of the New Deal era as part of a continuous historical thread); Barry Cushman, The Hughes Court and Constitutional Consultation, 1998 J. SUP. CT. HIST. 79, 80 [hereinafter Cushman, The Hughes Court] (arguing that the Hughes Court played a distinctly consultative role during the economic and political crises of the 1930s, supplying Congress with frequent constitutional counsel). Unlike Cushman, I think there is a real divide between pre- and post-1937 decisionmaking. After all, the New Deal Court, from 1937 to 1947, overturned thirty-two pre-1937 decisions. C. HERMAN PRITCHETT, The Roosevelt Court: A Study in Judicial Politics AND Values, 1937-1947, at 300-01 (1948); see also Schroeder, supra note 4, at 330 (reasoning that post-1937 decisions were not compelled by prior decisions). For further discussion, see infra note 91 and accompanying text (discussing the significance of the fact that the Rehnquist Court, while striking down numerous federal statutes, rarely calls earlier precedent into question).

9. Railroad Retirement Act, Pub. L. No. 73-485, 48 Stat. 1283 (1934), invalidated in R.R. Ret. Bd. v. Alton R.R. Co., 295 U.S. 330, 362 (1935).

10. Amendment of June 28, 1934 to $\S 75$ of the Bankruptcy Act of 1898, ch. 541, 30 Stat. 544, invalidated in Louisville Joint Stock Land Bank v. Radford, 295 U.S. 555, 602 (1935). 
minutes before registering its approval."11 Because Congress failed, among other things, to build a record to support the measure's impact on interstate commerce, Justices sympathetic to the statutory scheme complained that the government did not present its case in a convincing way. ${ }^{12}$

The Debt Relief Act likewise "inspired a storm of controversy [over] its validity." 13 Criticized as "one of the worst recent examples of draftsmanship in federal legislation," the bill was "hastily drafted and hurriedly passed" by a "harried Congress." 14 When signing the measure, Franklin Delano Roosevelt spoke of the bill as "loosely worded ... [and] requir[ing] amendment at the next session of Congress." ${ }^{15}$ These words proved prophetic, for, immediately after the act was invalidated in Louisville Joint Stock Land Bank v. Radford, ${ }^{16}$ Louis Brandeis, the opinion's author, lamented that "[t]he President has been living in a fool's paradise .... I should not be surprised if everything would have to be redrafted."

The Railroad Retirement and Debt Relief Acts typify early New Deal legislation-not well-drawn and tying "sweeping assertions of federal power to slap-dash justifications." 18 Senate Judiciary Chairman Henry Ashurst described the period this way: "We ground out laws so fast .... [we] reasoned from non-existent premises and, at times, we seemed to accept chimeras, phantasies and exploded social and economic theories as our authentic guides."19 Along the same lines, Justice Harlan Fiske Stone spoke of "[t]he general sloppiness of everything that has been done in connection with this effort" and his

11. William E. Leuchtenburg, The Supreme Court Reborn: The ConstitutionAL REVOlution IN THE AGE OF RoOseVelt 32 (1995).

12. For example, Benjamin Cardozo suggested that the Justice Department, by analogizing the statute "to a workman's compensation act," could have compensated for gaps left open by Congress. Id. at 41 (discussing a memorandum drafted by Justice Cardozo).

13. F. Carlisle Roberts, The New Frazier-Lemke Act-Its Provisions, Its Constitutionality, 22 A.B.A. J. 15, 15 (1936). For additional sources, see Cushman, The Hughes Court, supra note 8 , at 97 n.6.

14. Cushman, The Hughes Court, supra note 8 , at 81 (quoting various sources).

15. Roosevelt Signs Farm, Rail Bills, N.Y. TIMES, July 1, 1934, at 21.

16. 295 U.S. 555, 602 (1935).

17. Cushman, The Hughes Court, supra note 8, at 81 (quoting Richard D. Friedman, Charles Evans Hughes as Chief Justice, 1930-1941: The Complexities of Moderation 231 (1978) (unpublished Ph.D. dissertation, Oxford University)).

18. Michael Nelson, The President and the Court: Reinterpreting the Courtpacking Episode of 1937, 103 POL. SCI. Q. 267, 289 (1988).

19. Henry F. Ashurst, a Many Colored Toga: The Diary of Henry Fountain AsHuRsT 333 (1962). 
"hope that Congress will now undertake to do its job." ${ }^{20}$ Chief Justice Charles Evans Hughes complained that "the laws have been poorly drafted, the briefs have been badly drawn and the arguments have been poorly presented." 21

Failings of Congress, of course, tell only part of the story. After all, had the Court wanted to uphold these programs, the legal landmines that the Justices deployed to limit federal power never would have been devised in the first place. At the same time, the Court's willingness, starting in 1937, to sign on to the New Deal is partially attributable to Congress's decision to take the Court's rulings into account when crafting legislation. Unlike the "loose draftsmanship and emotional advocacy" of the First New Deal, observed Arthur Schlessinger, the laws of this "Second New Deal were masterpieces of the lawyer's art.",22

The lesson here is simple: Congress cannot turn its back on the Court and expect to get away with it. Indeed, public acceptance of judicial independence and supremacy ultimately proved damaging both to Roosevelt and his proposal to pack the Court with Justices "who will bring to the Courts a present-day sense of the Constitution."23 And while the Justices came to realize that the Court could not resist "the popular urge for uniform standards throughout the country," 24

20. Alpheus T. Mason, Harlan Fiske StOne: Pillar of the LaW 395 (1956) (quoting a letter from Harlan Fiske Stone to John Basset Moore dated May 30, 1935). Following the Court's invalidation of the Roosevelt administration's 1933 "hot oil" program, Justice Owen Roberts sounded a similar message, informing Interior Secretary Harold Ickes that he was "entirely sympathetic with what [the administration was] trying to do in the oil matter and that he hoped we would pass a statute that would enable [the administration constitutionally to] carry out [its] policy." 1 HAROLD L. ICKES, THE SECRET DiARY OF HAROLD L. ICKES: THE FIRST THOUSAND DAYs, 1933-36, at 273 (1953) (diary entry of Jan. 11, 1935).

21. Burton K. Wheeler with Paul F. Healy, Yankee from the West 329 (1962). On the issue of how poor Justice Department lawyering contributed to the Court's invalidation of early New Deal legislation, see Devins, supra note 8, at 251-53. See also Seth P. Waxman, Foreword: Does the Solicitor General Matter?, 53 STAN. L. REV. 1115, 1120 (2001) (contrasting the early New Deal period to today and, in so doing, arguing that Rehnquist Court efforts to limit congressional power are impervious to high quality government lawyering).

22. Arthur M. Schlessinger, JR., The Age of Roosevelt: The Politics of UPHEAVAL 395 (1960).

23. 6 Franklin D. Roosevelt, The Public Papers and Addresses of Franklin D. Roosevelt 127 (Samuel I. Rosenman ed., 1941). For analysis, see Richard Polenberg, REORGANIZING ROOSEVELT's GOVERNMENT 148-94 (1966) (detailing the fallout from Roosevelt's failed Court-packing plan); Barry Friedman, The History of the Countermajoritarian Difficulty, Part Four: Law's Politics, 148 U. PA. L. REV. 971, 1022-28 (2000) (highlighting public support for the Court during the Court-packing episode).

24. OWEN J. ROBERTS, THE COURT AND THE CONSTITUTION 61 (1951); see also CHARLES E. Hughes, THe Supreme Court of THE United StATES 24 (1928) (noting that, when the 
the Court, by calling attention to the poor quality of Congress's work, was able to cast Congress as a coconspirator in the demise of much early New Deal legislation.

What is striking here, as the next section of this Essay will detail, is how today's constitutional counterrevolution parallels the revolution of 1937. By giving short shrift both to Supreme Court decisions and to its own role as coequal interpreter of the Constitution, Congress has helped pave the way for the Rehnquist Court to reinvigorate the "Constitution in Exile."

\section{CONGRESS AND THE RETURN OF THE "CONSTITUTION IN EXILE"}

At the end of the Court's 2000 Term, Justice Antonin Scalia took aim at Congress. Complaining that "Congress is increasingly abdicating its independent responsibility to be sure that it is being faithful to the Constitution," ${ }^{25}$ Scalia minced no words in placing the blame for Court invalidations of federal statutes at Congress's door. Furthermore, Scalia made clear that the pace of Court rulings invalidating federal statutes is likely to quicken. "[I]f Congress is going to take the attitude that it will do anything it can get away with and let the Supreme Court worry about the Constitution," warned Scalia, "then perhaps th[e] presumption [of Congress acting constitutionally] is unwarranted."

Scalia's comments, of course, are self-serving. In pointing to Congress's misdeeds, Scalia (never hinting that the Court is sharply divided) suggested that the Justices have little choice but to strike down the abominations that Congress is throwing its way. ${ }^{27}$ More to

Court departs from "its fortress in public opinion," it may well suffer from self-inflicted wounds).

25. Taylor, supra note 1 , at 1811.

26. Id.

27. Here, I think, is where I part company with Professor Schroeder. While it is certainly true that increasingly negative attitudes toward the federal government help create the occasion for the Justices to engage in "motivated reasoning" and strike down federal legislation, I think Schroeder pays insufficient attention to the fact that the Court often divides five to four in these cases. See, e.g., Printz v. United States, 521 U.S. 898, 935 (1997) (invalidating part of the Brady Handgun Violence Prevention Act in a 5-4 decision); United States v. Lopez, 514 U.S. 549, 551 (1996) (invalidating the Gun-Free School Zones Act in a 5-4 decision); see also Schroeder, supra note 4, at 310 (mentioning that the central decisions of the post-Lopez Court are identical 5-4 votes). Specifically, if negative attitudes toward government explain the recent shift in Court decisionmaking, why are four Justices (including the two newest members of the Court) insensitive to this phenomenon? Indeed, had Al Gore become president, there is every reason to think that a Gore appointee would have discounted this growing distrust of Congress and, in so doing, shifted the balance on the Court to those favoring pro-Congress rulings. By way of contrast, as I 
the point, Scalia and other Justices willing to curtail Congress's powers are ideologically predisposed to limit lawmakers' prerogatives and, in so doing, to hear cases where they can point the finger at Congress for overstepping its enumerated powers. ${ }^{28}$ Nevertheless, there is reason to think that there are several kernels of truth in Scalia's rebuke. Congress does seem disinterested both in defending its turf as coequal interpreter of the Constitution and in thinking through the consequences of Supreme Court decisions. As a result, legislative drafting - as was true during the early New Deal-appears to be, at best, sloppy and, at worst, a direct invitation to the Court to strike down Congress's enactments.

In making this point, this section offers some anecdotal evidence about Congress-Court relations. My aim is not so much to offer definitive proof; instead, it is to detail why-based on my observations over the past several years-I have come to think that Congress has played a significant role in the ongoing imbroglio over the scope of its powers.

\section{A. Congress and Constitutional Interpretation}

Congress is increasingly abdicating its core powers, including its power to interpret the Constitution independently. ${ }^{29}$ Sometimes,

will detail in this Essay, the pace of legislative disinterest in the Court and the Constitution has played an instrumental role, but only in changing the attitudes of Supreme Court Justices already predisposed to disapprove of congressional intrusions into state functions. Here, Congress's apparent disinterest in the Court and the Constitution is emboldening; it makes these Justices feel increasingly certain that now is the time to slap Congress down (especially because of the growing distrust of Congress).

28. See, e.g., Reno v. ACLU, 521 U.S. 844, 858 (1997) (criticizing Congress for failing to hold legislative hearings or consider less restrictive alternatives); City of Boerne v. Flores, 521 U.S. 507, 529 (1997) (invoking Marbury v. Madison, 5 U.S. (1 Cranch.) 137 (1803), and condemning Congress for seeking to statutorily overturn a Court interpretation of the Constitution); Lopez, 514 U.S. at 563 (emphasizing Congress's failure to hold hearings or make findings concerning the impact of gun possession on interstate commerce).

29. On the question of congressional abdication of power, see generally LOUIS FISHER, CONGRESSiONAL ABDiCATION ON WAR \& SPENDing (2000) [hereinafter FisHer, ConGRESSIONAL ABDICATION] (assessing the implications of the shifting balance of power in the federal government as Congress abdicated its role in the areas of war and spending powers); DAVID SChOENBRod, POWER Without Responsibility: How CONGRESS ABUSES THE People Through Delegation 3-21 (1993) (suggesting that congressional delegation of power, beginning in the 1930s, short-circuits the democratic election process). On the question of Congress's role in interpreting the Constitution, see LOUIS FISHER, CONSTITUTIONAL Dialogues: Interpretation As Political Process 233-47 (1998) [hereinafter Fisher, CONSTITUTIONAL DiALOGUES] (arguing that the judiciary should not be the sole interpreter of the Constitution, but, rather, that the three branches must coordinate efforts to fuse law and politics in fostering a constitutional dialogue, from which a more comprehensive interpretation 
Congress treats the Constitution as the exclusive province of the Supreme Court; on other occasions, Congress simply seems indifferent to the constitutionality of its enactments, including whether the Supreme Court is likely to approve or disapprove of its decisionmaking. In so doing, Congress signals the Court that it has little institutional stake in constitutional matters and, accordingly, that there is little, if any, institutional price the Court will pay when invalidating federal legislation. With little reason to think about how its decisions will play on Capitol Hill, ${ }^{30}$ the Rehnquist Court's willingness to strike down federal legislation of which it disapproves is anything but surprising.

One manifestation of this phenomenon is the growing use of "expedited Supreme Court review" provisions in cases for which Congress finds its handiwork constitutionally suspect. Specifically, rather than sorting out the constitutionality of the legislation it is considering, Congress sometimes enacts a fast-track provision enabling litigants both to bypass the federal courts of appeal and to secure automatic Supreme Court review. ${ }^{31}$ Over the past several years, Congress has included expedited review provisions on several high-profile enactments, including flag burning legislation, ${ }^{32}$ the Gramm-Rudman Act, ${ }^{33}$ the Communications Decency Act, ${ }^{34}$ the Line Item Veto Act, ${ }^{35}$

will emerge); MARK TUSHNEt, TAKING THE CONSTITUTION AwAy FROM THE COURTS 194 (1999) (arguing for a method of constitutional interpretation that takes into account the populist views of the general public).

30. See Frank B. Cross, The Justices of Strategy, 48 DuKE L.J. 511, 529 (1998) (reasoning that the Justices rarely consider the possibility of a legislative override); Jeffrey A. Segal, Separation-of-Powers Games in the Positive Theory of Congress and Courts, 91 AM. POL. SCI. REV. 28, 31-32 (1997) (arguing that the high cost of congressional reversal and the many vetoes precluding such a reversal account for the Court's lack of concern for possible legislative overrides).

31. The precise terms of these expedited review provisions vary greatly, but most mandate Supreme Court review. See, e.g., Line Item Veto Act, Pub. L. No. 104-130, § 3, 110 Stat. 1200, 1211 (1996), invalidated in Clinton v. City of New York, 524 U.S. 417 (1998) (mandating Supreme Court review after trial in the United States District Court for the District of Columbia). Moreover, while the federal courts of appeal are almost always bypassed, it is sometimes the case that a three-judge district court panel will hear the initial challenge. Balanced Budget and Emergency Deficit Control Act of 1985, Pub. L. No. 99-177, § 274(a)(5), 99 Stat. 1038, 1098.

32. Flag Protection Act of 1989, Pub. L. No. 101-131, § 3, 103 Stat. 777, 777, invalidated in United States v. Eichman, 496 U.S. 310 (1998).

33. Balanced Budget and Emergency Deficit Control Act of 1985, Pub. L. No. 99-177, § 274(a)(5), 99 Stat. 1038, 1098.

34. Communications Decency Act of 1996, Pub. L. No. 104-104, § 561, 110 Stat. 133, 142 43, partially invalidated in Reno v. ACLU, 521 U.S. 844 (1997).

35. Pub. L. No. 104-130, § 3, 110 Stat. 1200, 1211 (1996), invalidated in Clinton v. City of New York, 524 U.S. 417 (1998). 
and census reform legislation. ${ }^{36}$ In all these statutes, the expedited review provision was not part of the original bill; instead, after constitutional objections were raised, Congress-rather than settle the issue itself-decided that it was best to hand the matter off to the Supreme Court. ${ }^{37}$

The Line Item Veto Act exemplifies how expedited review provisions, in effect, delegate Congress's power to interpret the Constitution to the Supreme Court. ${ }^{38}$ Although Senator Robert Byrd spoke of the oath that each member takes to "support and defend the Constitution," and, with it, Congress's responsibility to "be resolving those [constitutional] questions on [its] own, ${ }^{39}$ nearly all members were quite happy to leave the Act's constitutional fate solely in the hands of the Supreme Court. For example, Representative William Clinger, chairman of the House committee with jurisdiction over the bill, answered objections "that [the bill] is unconstitutional" by declaring: "It is not really our job to determine what is constitutional or what is not unconstitutional. ${ }^{, 40}$ Equally striking, Senator Paul Simon, a cosponsor of the bill, explained the provision requiring expedited Supreme Court review this way: "What we do not want is to live in limbo ....

36. Departments of Commerce, Justice, and State, the Judiciary, and Related Agencies Appropriations Act of 1998, Pub. L. No. 105-119, § 209, 111 Stat. 2240, 2482 (1997).

37. Consider, for example, census legislation enacted in 1997, supra note 36. Democrats and Republicans divided over the constitutionality of using statistical sampling to compensate for the historical undercounting of minorities. Compare 143 CONG. REC. H8222 (daily ed. Sept. 30, 1997) (statement of Rep. Hastert (R-IL)) (arguing that statistical sampling is unconstitutional), with id. at H8228 (statement of Rep. Watt (D-NC)) (arguing that statistical sampling is constitutional). To break this logjam, lawmakers included an expedited review provision "if the Census Bureau attempts to spend money on sampling in the 2000 Census." Jerry Gray, In Spending Bill, A Gauntlet on Census is Thrown Down, N.Y. TIMES, Oct. 23, 1997, at A23.

38. Before enacting the Line Item Veto Act, Congress held numerous hearings (over a number of years) concerning the constitutionality of a line-item veto. See FISHER, CONGRESSIONAL ABDiCATION, supra note 29, at 137-53 (detailing the legislative history of the Line Item Veto Act). On other occasions, however, Congress has added an expedited review provision to a measure without considering the pertinent constitutional issues in a meaningful way. See infra note 41 and accompanying text (discussing the expedited review procedures in the Gramm-Rudman Act).

39. 142 CONG. REC. 6509 (1996) (statement of Sen. Byrd (D-WV)).

40. Id. at 6912 (statement of Rep. Clinger (R-PA)). Indeed, to facilitate fast-track judicial review, Congress added a provision to the bill allowing lawmakers to challenge the statute even before President Clinton employed the line-item veto. In Raines v. Byrd, 521 U.S. 811 (1997), however, the Supreme Court concluded that lawmakers lacked standing to bring the case. Id. at 830 . 
[As to the legislation's constitutionality,] I do not know who is right. The courts have to make that determination." ${ }^{41}$

Not surprisingly, the Supreme Court struck down the Line Item Veto Act. ${ }^{42}$ The Justices almost always invalidate congressional statutes that contain expedited review provisions. ${ }^{43}$ And why not? Congress cannot possibly object to such Court decisions, for the expedited review provision makes clear that Congress sees itself as subordinate to the Court and, consequently, has little stake in the constitutional fate of its handiwork. ${ }^{44}$

There are other ways that Congress signals the Court that constitutional questions are the Court's domain. When deliberating about the Constitution's meaning, Congress often treats the Court's decisions as definitive and final. In other words, unlike Court-curbing periods (during which Congress has sought to limit the reach of Court decisions on, among other things, abortion, busing, and school

41. 141 Cong. REC. 8417 (1995) (statement of Sen. Simon (D-IL)). When Congress enacted an expedited review provision in the Gramm-Rudman Act, similar concerns were expressed. House Judiciary Chair Pete Rodino noted that "the constitutional problems with this measure" have not been resolved and "[t]hat is why the inclusion of a provision ... calling for quick judicial review is absolutely essential." 131 CONG. REC. 30,158 (1985) (statement of Rep. Rodino (D-NJ)). Along the same lines, Representative Jack Brooks remarked: "There is hardly anybody who can say with a straight face that Gramm-Rudman or any version of it is free of serious constitutional questions. It is vital that we have a mechanism in place to ensure that those questions get to court and be addressed directly." Id. at 30,150 (statement of Rep. Brooks (D-TX)); see also infra note 62 (discussing the expedited review provision in the Communications Decency Act).

42. Clinton v. City of New York, 524 U.S. 417, 421 (1998). I do not mean to suggest, however, that the Court's decision was a good one. See Neal Devins, Congressional Factfinding and the Scope of Judicial Review: A Preliminary Analysis, 50 DUKE L.J. 1169, 1188-93 (2001) (defending the constitutionality of line-item veto legislation).

43. See, e.g., Reno v. ACLU, 521 U.S. 844, 885 (1997) (invalidating portions of the Communications Decency Act); United States v. Eichman, 496 U.S. 310, 318 (1990) (invalidating flag protection legislation); Bowsher v. Synar, 478 U.S. 714, 734 (1986) (holding that section 251 of the Balanced Budget and Emergency Deficit Control Act violates the Constitution by permitting Congress to participate in the execution of its own laws). And when the Justices have not declared statutes unconstitutional, they still have been able to frustrate congressional objectives through statutory interpretation. See Dep't of Commerce v. United States House of Representatives, 525 U.S. 316, 343 (1999) (rejecting the planned use of statistical sampling during the 2000 census as inconsistent with the Census Act).

44. For a related argument, see Mark Graber, The Non-Majoritarian Difficulty: Legislative Deference to the Judiciary, 7 STUD. AM. POL. DEV. 35, 37-68 (1993) (arguing that lawmakers occasionally leave it to the courts to address contentious political issues the lawmakers could not adequately resolve). 
prayer $){ }^{45}$ the modern Congress hardly ever casts doubt on either the correctness of the Court's rulings or, more fundamentally, the Court's power to interpret the Constitution authoritatively. ${ }^{46}$

Consider, for example, Congress's response to Adarand Constructors, Inc. v. Pena, ${ }^{47}$ a 1995 Supreme Court decision declaring that federal affirmative action programs must satisfy the Court's strictest standard of judicial review. ${ }^{48}$ In the immediate wake of the Court's decision, Senator Phil Gramm proposed eliminating set-asides for minorities and women in federal contracting. Gramm explained, "my amendment is written in total conformity with Adarand. ... That is, if the court finds that a contractor was [personally] subject to discrimination, the court may provide a remedy with a set-aside ...."49 In sharp contrast, Senator Arlen Specter called attention to Adarand's recognition that the government may act in response to "both the practice and the lingering effects of racial discrimination." these lines, Senator Patty Murray countered Gramm's efforts by proposing that federal funds can be used only for "programs ... completely consistent with the Supreme Court's recent decision in... Adarand. ${ }^{, 51}$ In the end, the Murray amendment was approved by a

\footnotetext{
45. See Edward Keynes with Randall K. Miller, The Court vs. Congress: PRAYER, BUSING, AND ABORTION (1989) (providing a general treatment of Congress's power to curb the Court in certain areas).

46. For a historical overview of Court-curbing, see FISHER, CONSTITUTIONAL DiALOGUES, supra note 29, at 200-30. In arguing that today's Congress is accepting of the Court's "ultimate authority," I do not mean to suggest that members of Congress never express disappointment with the Court or, alternatively, that Congress never acts in response to Court decisions. My point, instead, is that Congress-notwithstanding the Court's increasing willingness to strike down federal legislation-is far more accepting of the Court today than it has been in the past. See infra notes 47-58 and accompanying text (discussing Congress's response to the recent wave of anti-Congress Rehnquist Court decisions).

47. 515 U.S. 200 (1995).

48. Id. at 237-38. While the Court remanded the case to the lower courts (and thereby did not rule on the constitutionality of a highway set-aside program), Adarand is the first case in which the Court refused to uphold a congressionally approved affirmative action plan. On the question of whether federal affirmative action legislation is poorly crafted, see Devins, supra note 42 , at 1200-06 (highlighting Congress's disinterest in building a factual record supporting affirmative action legislation).

49. 141 CONG. REC. 19,670 (1995) (statement of Sen. Gramm (R-TX)).

50. Id. at 19,671 (statement of Sen. Specter (R-PA)) (quoting Justice O'Connor's opinion in Adarand Constructors, Inc. v. Pena, 515 U.S. 200, 237 (1995)).

51. Id. at 19,667 (statement of Sen. Murray (D-WA)).
} 
lopsided 84-13 vote, and the Gramm amendment was soundly defeated by a bipartisan $61-36$ vote. $^{52}$

Two things stand out from this nonresponse to Adarand. First, everyone agreed that Adarand was the law of the land. Gramm did not build his case around the wrongness, as a matter of constitutional interpretation, of the government's decision to sometimes take race into account, ${ }^{53}$ Murray did not argue that Adarand was wrong in embracing strict review and, consequently, that Congress should defend existing affirmative action programs (and leave it for the Court, not Congress, to implement the Justices' understanding of things). Second, in sorting out what to do, the Senate thought it better to return this issue to the courts than to interpret Adarand independently. In particular, the Gramm amendment required the Senate to embrace a particular understanding of Adarand. The Murray amendment, in contrast, was so open-ended that it would not require Congress independently to adopt a particular understanding of Adarand. As a consequence, litigants challenging the program could seek a definitive answer as to what Adarand means by going to a higher authority than Congress, namely, the federal courts.

It is little wonder that Supreme Court Justices feel empowered by such legislative deliberations. By seeing the Constitution as the Supreme Court's domain, Congress encourages the Court to strike down measures the Justices dislike, to settle presidential elections, and so forth. ${ }^{54}$ And while the Justices may not know about the

52. Kevin Merida, Senate Rejects Gramm Bid to Bar Affirmative Action Set-Asides, WASH. PosT, July 21, 1995, at A13. More recently, in September 1997, then-Senator John Ashcroft sponsored hearings intended to demonstrate that federally funded set-asides were inconsistent with Adarand. Robert G. Kaiser \& Walter Pincus, Chief Foe as Chief Defender?: Ashcroft Critical of Laws, Decisions He Would Enforce, WASH. Post, Jan. 13, 2001, at A1. But, as it did with the Gramm proposal, the Senate left the matter alone, preferring to steer clear of the affirmative action wars rather than engage in a partisan fight over the propriety of preferences.

53. Gramm did argue, however, that affirmative action was bad public policy. See 141 CONG. REC. 19,670 (1995) (statement of Sen. Gramm (R-TX)) (arguing that "inequity" cannot be corrected by "making inequity the law of the land").

54. By deciding Bush v. Gore, 531 U.S. 98 (2000), the Supreme Court signaled that it, not Congress, was best positioned to settle the presidential election. Whether or not the Court doubted "the capacity of Congress to carry the burden of political leadership in conditions of constitutional stress," Frank I. Michelman, Suspicion, or the New Prince, 68 U. CHI. L. REV. $679,688-89$ (2001), there is little question that the Court thought it could decide the issue without destroying its institutional legitimacy. In this way, Bush v. Gore is very much like the Watergate tapes case, United States v. Nixon, 418 U.S. 683 (1974). In believing that "they could assure the legitimacy of the process and the legitimacy of the winner of the presidency," the members of the Court reached out to decide a fundamental question that, in critical respects, the Constitution delegated to the Congress. Gerald Gunther, A Risky Moment for the Court, 
Gramm-Murray exchange, they certainly know that a legislative backlash has not followed in the wake of recent rulings limiting congressional power. There is no talk of packing the Court, of stripping it of jurisdiction, ${ }^{55}$ or of amending the Constitution in response to these rulings. Moreover, these decisions played no role in the 2000 elections. ${ }^{56}$ Finally, Congress has shown relatively little interest in rewriting these statutes. ${ }^{57}$ And when Congress has revisited its handiwork, lawmakers have paid close attention to the Supreme Court's rulings, limiting their efforts to revisions the Court is likely to approve. ${ }^{58}$

N.Y. TIMES, Dec. 1, 2000, at A37; see also Gerald Gunther, Judicial Hegemony and Legislative Autonomy, 22 UCLA L. REV. 30, 33 (1974) (criticizing the Court for thinking that it has a "special obligation to save the nation in episodes of constitutional crisis"); Jeffrey Rosen, The Recount Is In, and the Supreme Court Loses, N.Y. TIMES, July 17, 2001, at A23 ("The dispute over the recount was political, not legal, and should have been resolved by Congress rather than by the courts.").

55. See infra notes 103-10 and accompanying text (describing how Congress is actually increasing the workload of the federal judiciary, much to the Court's dismay).

56. For an explanation, published before the election, as to why this is so, see Taylor, supra note 1, at 1818-19 (examining why voters "have far more confidence in the Supreme Court than in Congress ... [and] the executive branch").

57. In sharp contrast, following the Court's invalidation of early New Deal legislation, the New Deal Congress reworked several statutes. Cushman, The Hughes Court, supra note 8, at 81-97.

58. Of the twenty-three statutes struck down by the Court between 1995 and 2000, Congress revised four of them. First, in 1996, Congress responded to United States v. Lopez, 514 U.S. 549 (1995), a Supreme Court decision invalidating the Gun-Free School Zones Act of 1990. $I d$. at 567. Under the new statute, the federal government must prove that the firearm has "moved in or otherwise affects interstate or foreign commerce." 18 U.S.C. $\S 922(q)(2)(A)$ (Supp. V 1999); see Guns in Schools: A Federal Role?: Hearing Before the Subcomm. on Youth Violence of the S. Comm. on the Judiciary, 104th Cong. 9 (1995) (statement of Walter Dellinger, Assistant Attorney General, Office of Legal Counsel) (explaining how the statute conforms to Lopez). Second, in 1998, following the Court's repudiation of portions of the Communications Decency Act (CDA) in Reno v. ACLU, 521 U.S. 844, 885 (1997), Congress enacted the Children's Online Protection Act, 15 U.S.C. §§ 6501-6506 (Supp. V 1999). “[A]ddress[ing] the specific concerns raised by the Supreme Court," the Act responds to several of the Court's criticisms of the CDA, including the lack of legislative hearings, the failure to consider less restrictive alternatives, and the overbroad definition of what constitutes indecency. H.R. REP. No. 105-775, at 12 (1998). Third, in 2000, Congress responded to City of Boerne v. Flores, 521 U.S. 507 (1997), a Supreme Court decision invalidating the Religious Freedom Restoration Act (RFRA) as an improper exercise of Congress's powers under Section 5 of the Fourteenth Amendment. Id. at 536. The new statute, the Religious Land Use and Institutionalized Persons Act of 2000, 42 U.S.C. 2000cc to 2000cc-5 (Supp. V 1999), narrows the scope of RFRA protections to categories Congress thinks satisfy the Boerne standard or make use of its spending and commerce powers. See 146 CONG. REC. S7774-75 (daily ed. July 27, 2000) (remarks of Sen. Hatch (R-UT)) (detailing sources of constitutional authority for the statute and, in so doing, explaining why the statute conforms to Boerne). Fourth, also in 2000, Congress enacted the Violence Against Women Act of 2000, Pub. L. No. 106-386, 114 Stat. 1491. This statute, however, is concerned principally with federal funding directed at the prevention of domestic vio- 


\section{B. Congress and the Drafting of Constitutional Legislation}

That Congress sometimes equates Supreme Court decisionmaking with the Constitution speaks more of legislators' interest in achieving desired political outcomes than anything else. Opponents of legislation, when raising constitutional objections, are on firmer footing when they suggest that the federal courts will strike down a measure. And, as was true with Phil Gramm's effort to undo setasides, proponents of initiatives likewise seek to bolster their case by claiming that they are simply effectuating the decisions of the Supreme Court. Moreover, by embracing expedited review provisions (that short-circuit fights over a measure's constitutionality), bill supporters help to secure passage of a favored measure. Finally, when recrafting legislation in accordance with a Supreme Court decision, Congress often is motivated by the interests of the constituencies that supported the legislation in the first place.

Just as talk of the Court's status as ultimate interpreter of the Constitution may be a rhetorical device used to pursue political ends, it is to be expected that Congress sometimes ignores the Court in order to pursue a political end. For this reason, I think it especially useful to examine some recent occasions in which Congress seemed, at best, indifferent to the Court. Before turning to these examples, a few words on why the recent spate of anti-Congress Rehnquist Court rulings is, in part, a by-product of such legislative indifference. Specifically, just as talk of judicial supremacy encourages the Court to see itself as supreme and, consequently, to place more and more constraints on Congress, legislative indifference to Court rulings creates more and more occasions in which Congress will run afoul of those ever-increasing constraints. And if Congress fails to challenge the Court by asserting its independent voice in interpreting the Constitu-

lence. H.R. REP. NO. 106-891, at 24 (2000). No effort was made to revive the right-to-sue provision struck down in United States v. Morrison, 529 U.S. 598, 627 (2000) (holding that Congress did not have the power, either under the Commerce Clause or Section 5 of the Fourteenth Amendment, to provide all victims of gender-motivated crime with a federal civil remedy).

Congress, moreover, embraced Department of Transportation efforts to modify its regulatory scheme in response to Adarand Constructors, Inc. v. Pena, 515 U.S. 200 (1995). Noting that "the Department has proposed a number of regulations intended to address the "narrow tailoring' requirements of 'strict scrutiny,"' H.R. CONF. REP. NO. 105-550, at 410-11 (1998), reprinted in 1998 U.S.C.C.A.N. 70, 82-83, Congress, in 1998, reauthorized the disadvantaged business enterprise program that was the subject of the Adarand litigation. Transportation Equity Act for the 21st Century, Pub. L. No. 105-178, 112 Stat. 107 (1998). 
tion, the Court is apt to grow less and less tolerant of such congressional lapses and create even more constraining doctrine.

Two recent examples of Congress giving short shrift to both the Constitution and the Supreme Court stand out: the Communications Decency Act $(\mathrm{CDA})^{59}$ and the Religious Freedom Restoration Act (RFRA).$^{60}$ When enacting the CDA (introduced on the Senate floor as an amendment to a massive telecommunications bill), Congress ignored Clinton administration warnings to hold hearings on the bill's constitutionality. ${ }^{61}$ Rather, as Senator Patrick Leahy described: "[We] went willy-nilly, pass[ing] legislation, and never once . . . [having] a discussion other than an hour or so on the floor." ${ }^{12}$ The result was a bill that "[n]o one, not even its defenders, claims ... was drafted elegantly or even consistently." ${ }^{63}$ A unanimous Supreme Court agreed, noting the lack of hearings, inconsistencies in the bill's use of the term "indecent," and Congress's failure to consider less burdensome alternatives. ${ }^{64}$

RFRA is an even more outrageous example of Congress's indifference to how its legislation would fare before the Supreme Court. ${ }^{65}$ Here, Congress, in response to a restrictive Supreme Court interpretation of Free Exercise Clause protections, attempted to justify its actions as a permissible exercise of its enforcement powers under Section 5 of the Fourteenth Amendment. ${ }^{66}$ But Congress ignored the

59. Communications Decency Act of 1996, Pub. L. No. 104-104, 110 Stat. 133, partially invalidated in Reno v. ACLU, 521 U.S. 844 (1997).

60. Pub. L. No. 103-141, 107 Stat. 1488 (1993), invalidated in City of Boerne v. Flores, 521 U.S. 507 (1997).

61. See John Schwartz, On-Line Obscenity Bill Gains in Senate, Panel Backs Legislation, Critics See Threat to First Amendment, WASH. Post, Mar. 24, 1995, at A1 (quoting White House spokeswoman Ginny Terzano's call for a "serious approach—such as hearings— to find the best solution").

62. Cyberporn and Children: The Scope of the Problem, The State of the Technology, and the Need for Congressional Action: Hearings Before the S. Comm. on the Judiciary, 104th Cong. 7 (1995) (statement of Sen. Leahy (D-VT)). Perhaps for this reason, an expedited review provision was added to the CDA. See 142 Cong. REC. 2662 (1996) (statement of Sen. Leahy) (noting that "such serious questions about the constitutionality of this legislation have been raised that a new section was added to speed up judicial review to see if the legislation would pass constitutional muster").

63. Peter D. Kennedy, The Supreme Court and Cyberspace: Pending Challenges to the Communications Decency Act, CoMM. L., Fall 1996, at 3, 3.

64. Reno v. ACLU, 521 U.S. at 858.

65. For a detailed treatment of this subject (from which this paragraph draws), see generally Neal Devins, How Not to Challenge the Court, 39 WM. \& MARY L. REV. 645 (1998).

66. In this way, Congress could have expressed its (quite justified) disapproval of the Supreme Court's religious liberty decisionmaking without demanding that the Court overrule it- 
advice of law professors who testified that it should make specific findings of fact "that formally neutral, generally applicable laws have historically been instruments of religious persecution, that enacting separate religious liberty exemptions in every statute is not a workable means of protecting religious liberty, and that litigation about governmental motives is not a workable means of protecting religious liberty." "Instead, Congress condemned the Court for its "disastrous," tion," if not "virtual[] eliminat[ion,]" of religious liberty protections. And while RFRA's interest-group sponsors may have welcomed such vitriol, the Supreme Court, in City of Boerne v Flores, ${ }^{73}$ rebuffed Congress for seeking to statutorily overturn a Court interpretation of the Constitution..$^{74}$ More fundamentally, the Court expressed skepticism of Congress by embracing a standard of review that has further curtailed Congress's Section 5 enforcement powers. ${ }^{75}$

self. And because the Court (in a decision issued in the midst of legislative consideration of the Religious Freedom Restoration Act) had made clear that "to overrule under [political] fire ... would subvert the Court's legitimacy beyond any serious question," lawmakers should have acted judiciously when seeking to chasten the Court for its restrictive reading of First Amendment religious liberty protections. Planned Parenthood v. Casey, 505 U.S. 833, 867 (1992). Instead, lawmakers acted with reckless abandon. See Devins, supra note 42, at 1196, 1197 (arguing that Congress gave "short shrift to factfinding" when enacting RFRA).

67. Religious Freedom Restoration Act of 1991: Hearings Before the Subcomm. on Civil and Constitutional Rights of the Comm. on the Judiciary, 102d Cong. 331 (1992) (testimony of Professor Douglas Laycock); see also id. at 390-91 (testimony of Professor Ira C. Lupu) (calling attention to the need for Congress to show that RFRA is grounded in "legislative superiority in fact-finding" and not Congress's disapproval with the "direction and result" of Supreme Court decisionmaking).

68. 139 CONG. REC. 9683 (1993) (statement of Rep. Nadler (D-NY)).

69. 137 CONG. REC. 17,035-36 (1991) (statement of Rep. Solarz (D-NY)).

70. 139 CONG. REC. 9684 (1993) (statement of Rep. Schumer (D-NY)).

71. Id. at 9685 (statement of Rep. Orton (D-UT)).

72. Id. at 9683 (statement of Rep. Nadler (D-NY)).

73. 521 U.S. 507 (1997).

74. Id. at 535-36. While no Justice took issue with the Court's conclusion that Congress had overstepped its bounds, three Justices would have reconsidered the Court's restrictive approach toward religious liberty claims. Id. at 544-66 (Souter, Breyer, O'Connor, JJ., dissenting).

75. Since its decision in Boerne, the Court has invalidated three other federal statutes as impermissible exercises of Congress's Section 5 enforcement powers. See Bd. of Trs. of the Univ. of Ala. v. Garrett, 531 U.S. 356, 121 S. Ct. 955, 967-68, (2001) (partially invalidating the Americans with Disabilities Act on the ground that it conflicts with the Eleventh Amendment); Kimel v. Fla. Bd. of Regents, 528 U.S. 62, 91 (2000) (holding Congress's abrogation of states' sovereign immunity in the Age Discrimination in Employment Act to be unconstitutional); Fla. Prepaid Postsecondary Educ. Bd. v. College Sav. Bank, 527 U.S. 627, 647 (1999) (invalidating the Patent Remedy Act as an unconstitutional abrogation of state immunity that cannot be justified by Congress's Section 5 enforcement power). 
Congress, however, has not paid much mind to this tightening of its Section 5 powers. A search of the Congressional Record reveals that members of Congress have mentioned the precedential value of Boerne on only nine occasions. ${ }^{76}$ Congress's apparent disinterest in Boerne is the rule, not the exception, when it comes to recent Court decisions limiting congressional prerogatives. United States v. Lopez, ${ }^{77}$ the case that invalidated the Gun-Free School Zones Act, also has received scant attention in congressional debates. Notwithstanding the fact that Lopez was the first case in more than sixty years to declare a federal statute outside Congress's Commerce Clause power (and that it has since proven an instrumental precedent in invalidating the Violence Against Women Act ${ }^{78}$, members of Congress have mentioned the case's precedential value only sixteen times since 1995, the year Lopez was decided. ${ }^{79}$ Finally, the Court's anticommandeering cases, Printz v. United States ${ }^{80}$ and New York v. United States ${ }^{81}$ have not figured into congressional deliberations. The precedential value

76. See LEXIS database search, Congressional Record, All Congress Combined, from June 25, 1997 (the date of the Boerne decision) to July 24, 2001; see, e.g., 146 CONG. REC. E1235 (daily ed. July 14, 2000) (remarks of Rep. Canady (R-FL)) (defending the Religious Land Use and Institutionalized Persons Act as a protection of free exercise not subject to the challenges raised in Boerne); 146 CONG. REC. S3973 (daily ed. May 16, 2000) (statement of Sen. Biden (DDE)) (citing Boerne as testament to the Court's willingness to second-guess Congress's legislative judgment and assert itself as the authoritative interpreter of the Constitution). On nine other occasions, Boerne was mentioned-six times in connection with the scheduling of hearings and three times in connection with the inclusion of letters and memos into the Record. Boerne also was mentioned six times in connection with efforts to revamp the Religious Freedom Restoration Act.

77. 514 U.S. 549 (1995).

78. See United States v. Morrison, 529 U.S. 598, 619 (2000) (concluding that the Commerce Clause did not give Congress the authority to enact the Violence Against Women Act).

79. See LEXIS database search, Congressional Record, All Congress Combined, from April 26, 1995 (the date of the Lopez decision) to July 24, 2001; see, e.g., 146 CONG. REC. H7533 (daily ed. Sept. 13, 2000) (statement of Rep. Hutchinson (D-AR)) (characterizing the Lopez decision as a warning that congressional power under the Commerce Clause is subject to outer limits); 146 CONG. REC. S7775 (daily ed. July 27, 2000) (joint statement of Sen. Hatch (R-UT) and Sen. Kennedy (D-MA)) (noting that the Gun-Free School Zones Act and the Violence Against Women Act were struck down because they regulated noneconomic activity). In 1995, Lopez's precedential value was mentioned ten times by members of Congress. On nine other occasions, the case was mentioned in connection with letters and memoranda entered into the Congressional Record. Lopez also was mentioned five times in connection with efforts to revamp the laws regarding guns in schools.

80. 521 U.S. 898 (1997).

81. 505 U.S. 144 (1992). 
of New York has been mentioned by members of Congress six times $;{ }^{82}$ the precedential value of Printz has been mentioned twice. ${ }^{83}$

While these measures are somewhat artificial, they are nonetheless telling. At a minimum, they suggest that Congress is not paying much attention to the signals the Court is sending it. Correspondingly, Congress seems more and more willing to jeopardize its legislative work through sloppy drafting. ${ }^{84}$ On federalism-related issues, for example, the federal laws struck down "were quite poorly or negligently drafted." ${ }^{, 5}$ In Lopez, Congress failed to engage in factfinding, make a jurisdictional statement, or otherwise consider the constitutionality of its handiwork. ${ }^{86}$ In the Violence Against Women Act, Congress did assemble a "mountain of data... showing the effects of violence against women on interstate commerce." ${ }^{87}$ At the same time, by

82. See LEXIS database search, Congressional Record, All Congress Combined, from June 19, 1992 (the date of the New York decision) to July 24, 2001; see, e.g., 145 CONG. REC. S3909 (daily ed. Apr. 20, 1999) (statement of Sen. Lott (R-MS)) (asserting that his changes to the National Salvage Motor Vehicle Consumer Protection Act were consistent with the decision in New York v. United States); 144 CONG. REC. S5100 (daily ed. May 19, 1998) (statement of Sen. Hatch (R-UT)) (arguing that decisions like New York and Printz have made the Tenth Amendment a shield against federal imposition on the sovereign authority of the states).

83. See LEXIS database search, Congressional Record, All Congress Combined, from June 27, 1997 (the date of the Printz decision) to July 24, 2001; see, e.g., 146 CONG. REC. S7777 (daily ed. July 27, 2000) (joint statement of Sen. Hatch (R-UT) and Sen. Kennedy (D-MA)) (arguing that the Religious Land Use and Institutionalized Persons Act complies with Printz because it does not "compel the states to enact or enforce a regulatory program"). On several other occasions, however, members of Congress have introduced letters, memoranda, and resolutions that mention these cases - thirteen times for New York and three times for Printz. See Matthew D. Adler \& Seth F. Kreimer, The New Etiquette of Federalism: New York, Printz, and Yeskey, 1998 SUP. CT. REV. 71, 138 (discussing the paucity of references to New York and Printz).

84. See supra notes 59-75 and accompanying text (discussing how poor legislative drafting helped doom the Communications Decency Act, the Religious Freedom Restoration Act, and other high-profile enactments).

85. Michael J. Gerhardt, Federal Environmental Regulation in a Post-Lopez World: Some Questions and Answers, 30 ENVTL. L. REP. 10980, 10989 (2000). Several of the examples that follow are drawn from Professor Gerhardt's article.

86. See Devins, supra note 42, at 1194. The fact that the Supreme Court had not signaled (through pre-Lopez decisionmaking) that such factfinding might be relevant to its assessment of the statute does not excuse Congress's sloppiness. In critical respects, Lopez responded to Congress's increasingly cavalier attitude toward the scope of its Commerce Clause powers. In particular, Congress federalized all sorts of things without engaging in factfinding or contemplating the ways in which such federalization expanded the workload of federal judges. See infra notes 106-10 and accompanying text (discussing how federalization affected the federal judiciary). And while a Supreme Court with different values would not have interceded, the Court's action in Lopez - notwithstanding the lack of prior notice-can be understood as a response to Congress's negligence.

87. United States v. Morrison, 529 U.S. 598, 628-29 (2000) (Souter, J., dissenting). Congress assembled this data to respond to complaints that the statute had little to do with com- 
grounding the statute in both Section 5 of the Fourteenth Amendment and the Commerce Clause, Congress disregarded the wellsettled rule that it could not use its Section 5 power to regulate private conduct. ${ }^{88}$ And in several cases restricting Congress's Section 5 powers, Congress's factfinding was too limited or nonexistent. ${ }^{89}$ In particular, Congress failed to convince the Court that it was responding to a nationwide problem involving both state and private actors. $^{90}$ For these very reasons, the Court, while invalidating scores of federal laws, has had to overturn only three of its precedents. ${ }^{91}$

Making matters worse, Congress had every reason to expect that the Court would make it pay a price for its sloppiness. For example, in both the Gun-Free School Zones Act and the Violence Against Women Act, Congress enacted legislation federalizing crime over objections by both the Judicial Conference and Chief Justice Rehnquist. ${ }^{92}$ More to the point, since most states bar gun possession

merce. See infra note 92 and accompanying text (noting objections to the statute voiced by both the Judicial Conference and Chief Justice William Rehnquist). The majority, while not disputing this assertion, concluded that violence against women was "noneconomic." Morrison, 529 U.S. at 613 .

88. Morrison, 529 U.S. at 619-24.

89. For example, when enacting the Religious Freedom Restoration Act, Congress failed to make the types of findings needed to show that a national solution was necessary. See supra note 67 and accompanying text.

90. See supra notes 65-75 and accompanying text (discussing RFRA); see also Bd. of Trs. of the Univ. of Ala. v. Garrett, 531 U.S. 356, 121 S. Ct. 955, 965-66 (2001) (discussing congressional failure to establish the historical basis of state discrimination against the disabled); Kimel v. Fla. Bd. of Regents, 528 U.S. 62, 89 (2000) ("Congress never identified any pattern of age discrimination by States, much less any discrimination whatsoever that rose to the level of constitutional violation."); Fla. Prepaid Postsecondary Educ. Expense Bd. v. College Sav. Bank, 527 U.S. 627, 640 (1999) (observing that Congress did not identify a "pattern of patent infringement by the States, let alone a pattern of constitutional violations").

91. See College Sav. Bank v. Fla. Prepaid Postsecondary Educ. Expense Bd., 527 U.S. 666, 680 (rejecting the constructive waiver doctrine of Parden v. Terminal Railway of the Alabama Docks Department, 377 U.S. 184 (1964)); Seminole Tribe v. Florida, 517 U.S. 44, 66 (1996) (rejecting Congress's power to abrogate the Eleventh Amendment via a statute enacted under the Commerce Clause, overturning Pennsylvania v. Union Gas Co., 491 U.S. 1 (1989)); Adarand Constructors, Inc. v. Pena, 515 U.S. 200, 227 (1995) (holding that federal affirmative action programs are subject to strict scrutiny review, not intermediate scrutiny review, overturning Metro Broadcasting, Inc. v. FCC, 497 U.S. 547 (1990)).

92. Rehnquist, in 1992, wrote that Congress ought to "avoid adding new federal causes of action unless critical to meeting important national interests that cannot otherwise be satisfied through non-judicial forums, alternative dispute resolution techniques or the state courts." William H. Rehnquist, Congress Is Crippling Federal Courts, Ever-Expanding Number of 'Federal' Crimes; Belong in State Courts Instead, ST. Louis Post-DisPATCH, Feb. 16, 1992, at 3B. The Judicial Conference also expressed opposition to both the federalization of crime and the Line Item Veto Act, arguing that it would threaten judicial independence by expanding the presi- 
in school and every state provides civil remedies for gender-related violence, ${ }^{93}$ the Court may well have seen these attempts to expand the scope of federal power as little more than Congress pandering to popular sentiment.

No doubt, a Court with different values may have welcomed-as Senator Joseph Biden put it-Congress's federalizing “"everything that walks, talks, and moves." "94 The Rehnquist Court, however, is not that Court. Rather than look the other way, it seized upon Congress's sloppiness. ${ }^{95}$ Put another way, Congress had significant control over its fate. Had Congress acted more cautiously, the Rehnquist Court may have deferred the return of the "Constitution in Exile." 96

\section{Congress and the Management of the Federal Judiciary}

Congress has jeopardized its relationship with the Supreme Court further through its handling of several matters affecting the day-to-day lives of federal judges, including judicial salaries, the pace of judicial confirmations, and a range of issues affecting federal judges' workloads. And while some of these matters have no direct relationship to Court decisionmaking on federalism-related issues, it is nevertheless true that the attitudes of federal judges, including Su-

dent's power over judicial salaries. See id. (discussing federalization of crime); Jan Crawford Greenburg, Judges Back on Political Hot Seat, Controversial Ruling Sparks Criticism, CHI. TRIB., Apr. 3, 1996, at 1 (discussing line-item veto legislation). After Congress (responding to Judicial Conference objections) revamped the Violence Against Women Act, the Judicial Conference took no position on the legislation. For an account of this episode, see Judith Resnik, The Programmatic Judiciary: Lobbying, Judging, and Invalidating the Violence Against Women Act, 74 S. CAL. L. REV. 269, 270-274 (2000).

93. See Steve France, Laying the Groundwork, 86 A.B.A. J. 40, 42 (2000) (characterizing the Gun-Free School Zones Act, the Religious Freedom Restoration Act, and the Violence Against Women Act as "busybody legislation").

94. Dan Freedman, FBI Criticizes Trend Towards "Federalizing," Agents Don't Want to Be Street Cops, Hous. CHron., Dec. 19, 1993, at A2 (quoting Sen. Biden (D-DE)).

95. Professor Keith Whittington, in his response to Professor Schroeder's paper, puts it this way: "The federalism offensive can best be understood as a product of the Court's taking advantage of a relatively favorable political environment to advance a constitutional agenda of particular concern to some individuals within the Court's conservative majority." Keith E. Whittington, Taking What They Give Us: Explaining the Court's Federalism Offensive, 51 DuKE L.J. 477, 479 (2001).

96. The fact that the Rehnquist Court often divides 5-4 on federalism-related issues bolsters this claim. Specifically, if any member of the Rehnquist Court majority had been influenced by Congress's cavalier approach to federalism-related issues, the Court would have lacked the majority it needed to push through its federalism counterrevolution. See infra note 128 (collecting sources that suggest that Congress still retains the power to pursue initiatives that the Rehnquist Court has invalidated on federalism-related grounds). 
preme Court Justices, toward Congress are affected by Congress's management of issues related to the judiciary. In other words, a Court that has doubts about Congress's trustworthiness will find it easier to constrain Congress than will a Court that has a high regard for Congress. ${ }^{97}$

Over the past five years, Chief Justice Rehnquist has used his year-end report on the federal judiciary to encourage Congress to live up to its responsibility "to enable the judges to do a better job of administering justice." ${ }^{, 98}$ Consider, for example, judicial salaries. In 1996, Rehnquist complained that Congress's failure to pay judges a competitive salary "cannot be overstated in terms of its effects on the morale and quality of the federal judiciary." "Four years later, in supporting the repeal of a congressional ban on honoraria, Rehnquist pointed to the fact that "'a first-year associate in a law firm could make as much in salary as a federal judge,"” and again argued that Congress was undermining " "the ability of the judiciary to retain and recruit the most capable lawyers." "100 Making matters worse, Congress-from 1997 to 1999_refused to make cost-of-living adjustments to judicial salaries. ${ }^{101}$ And while Congress's action may be more a result of the politics surrounding congressional pay than anything else, lawmaker insensitivity to judicial salaries nevertheless harmed Congress-Court relations. ${ }^{102}$

Far more damaging to Congress-Court relations, however, is a constellation of interconnected issues involving both the workload of federal judges and the types of cases that federal judges hear. First, the total number of cases filed in the federal courts of appeals has in-

97. In making this point, I do not mean to suggest that Supreme Court Justices would knowingly retaliate against Congress for its poor management of judiciary-related issues. My point, instead, is that there is a correlation between attitudes toward government and Supreme Court decisionmaking. See Schroeder, supra note 4, at 346-51 (discussing the impact of public distrust of government on the growing opposition to federalization).

98. William H. Rehnquist, 1996 Year-End Report on the Federal Judiciary, at http://www. uscourts.gov/cj96.htm (last visited Aug. 21, 2001) (on file with the Duke Law Journal).

99. Id.

100. Judges and Honoraria, WASH. Post, Sept. 16, 2000, at A18.

101. See Underpaid Federal Judges, CHI. TRIB., July 26, 1999, at 10 (noting that a lawsuit by federal judges to receive cost-of-living adjustments may have been mooted by a new appropriations bill that permitted such raises).

102. Judicial salary increases typically are tied to congressional pay. In 1997, however, Congress forgot to include a salary increase for federal judges. Pay Freeze Raises Tension Between Congress, Federal Judges, DALLAs MoRning News, Oct. 21, 1997, at 4A. 
creased more than seventy percent over the past two decades. ${ }^{103}$ During the same period, federal district courts saw the total number of criminal cases increase by fifty percent, with drug cases tripling. ${ }^{104}$ As a result, "[c]ivil cases are often placed on the back burner, in some jurisdictions, as the judges try to cope with the flood of drug and gun cases." ${ }^{105}$

Second, Congress has contributed to this explosion of federal litigation by increasingly federalizing matters (especially crime). ${ }^{106}$ More than " 40 percent of federal criminal provisions enacted since the Civil War have been enacted since 1970."107 Among other things, Congress has criminalized many things that the states already outlaw, including drug crimes, carjacking, failure to pay child support, embezzlement from an insurance company, drive-by shootings, and possession of a handgun near a school. ${ }^{108}$ For their part, the federal courts have resisted this increasing federalization. In 1995 and again in 1998, the Judicial Conference lobbied Congress to "commit itself to conserving the federal courts as a distinctive forum of limited jurisdiction in our system of federalism." ${ }^{109}$ Chief Justice Rehnquist, moreover, used his bully pulpit to warn Congress of the costs of federalizationclogging the courts' dockets, overworking federal judges, changing

103. Between 1981 and 1991, there was a sixty percent increase. L. RALPH MECHAM, Admin. OfFICE of THE U.S. COURTS, 1991 AnNuAl Report of the Director 81 tbl.1 (1992). With Congress's continuing commitment to federalization, the number of filings is still increasing. By 1996, filings in the federal courts of appeals had risen to an all-time high of 52,000. See Rehnquist, supra note 98. By 2000, filings increased another four percent to 54,697. William H. Rehnquist, 2000 Year-End Report of the Federal Judiciary, at http://www.uscourts. gov/ttb/jan01ttb (last visited Aug. 21, 2001) (on file with the Duke Law Journal).

104. MECHAM, supra note 103, at 90 tbl.8. Since that time, criminal filings have continued to rise. From 1994 to 2000, criminal filings rose every year. See Rehnquist, supra note 103. In 1998, federal courts saw a double-digit increase in criminal filings. William H. Rehnquist, 1998 YearEnd Report of the Federal Judiciary, at http://www.uscourts.gov/ttb/jan99ttb/january1999.html (last visited Aug. 21, 2001) (on file with the Duke Law Journal).

105. Letter from J. Clifford Wallace, Chief Judge, U.S. Court of Appeals for the Ninth Circuit, to William H. Rehnquist, Chief Justice, U.S. Supreme Court; Janet Reno, U.S. Attorney General; Joseph Biden, Chair, Senate Judiciary Committee; Jack Brooks, Chair, House Judiciary Committee (Mar. 29, 1993), reprinted in William P. Marshall, Federalization: A Critical Overview, 44 DePAul L. ReV. 719, 739 (1995).

106. See generally William P. Marshall, American Political Culture and the Failures of Process Federalism, 22 HARV. J.L. \& PUB. POL'Y 139, 142-47 (1998) (describing this phenomenon and offering an explanation of why Congress federalizes so many areas of legal concern).

107. John J. Mountjoy, The Federalization of Criminal Laws, SPECtRum, Summer 1999, at $1,1$.

108. This list is taken from Edwin Meese III, Big Brother on the Beat: The Expanding Federalization of Crime, 1 TEX. REV. L. \& POL. 1, 3 (1997).

109. Rehnquist, supra note 104. 
the character of the types of cases that federal judges adjudicate, and, perhaps most significantly, damaging "our system of federalism.",

Third, Congress (as far as federal judges are concerned) added insult to injury both by failing to create additional judgeships to meet a litigation explosion that is largely its making and by holding up judicial and Sentencing Commission nominations. All of these matters have figured prominently in Rehnquist's year-end reports on the federal judiciary. In January 1998, Rehnquist depicted the Senate's failure to confirm judicial nominees as threatening to " "erod[e] the quality of justice." "111 Again in January 1999, he spoke of the need-with the increasing federalization of crime-to have "a fully functioning Sentencing Commission" and described the "political impasse" between the President and Congress as "stunning." 112 Finally, in January 1998 and January 2000, he spoke of the need for Congress to "eliminate the disparity between resources and workload in the Federal judiciary by ... [expanding] . . . the number of judges."113

Court-Congress relations, for the reasons detailed above, have been at a low ebb during the Rehnquist years. ${ }^{114}$ And while judges'

110. Id.; see also id. (calling for a reexamination of diversity jurisdiction, claiming that "there is no good reason to keep [these lawsuits] in federal court"); William H. Rehnquist, 1999 YearEnd Report on the Federal Judiciary, at http://www.uscourts.gov/ttb/jan00ttb/jan2000.html (last visited Aug. 21, 2001) (on file with the Duke Law Journal) (calling attention to the increasing federalization of crime and arguing for the elimination of "unwarranted federalization" to "help control growth in federal courts and preserve them as courts of limited jurisdiction"); supra note 92 and accompanying text (noting Rehnquist's objection to the Violence Against Women Act).

111. John H. Cushman, Jr., Senate Imperils Judicial System, Rehnquist Says, N.Y. TIMES, Jan. 1, 1998, at A1 (quoting Chief Justice Rehnquist). At that time, one in ten judgeships had been vacant with several of the vacancies in existence for eighteen or more months. Id.

112. Rehnquist, supra note 104. When Rehnquist issued this statement, there were no commissioners on the Sentencing Commission and no nominations pending. Id. It is also noteworthy that the Sentencing Commission, by severely limiting judicial discretion at sentencing, removed significant discretionary authority from the courts and vested that power in Congress. James B. Burns et al., We Make the Better Targets (But the Guidelines Shifted Power from the Judiciary to Congress, Not from the Judiciary to the Prosecution), 91 Nw. U. L. REV. 1317, 1317-21 (1997).

113. William H. Rehnquist, 1997 Year-End Report on the Federal Judiciary, excerpted in Judiciary Report: Congress is Prodded, N.Y. TIMES, Jan. 1, 1998, at A14; see also Rehnquist, supra note 103 (commending Congress for creating ten new district judgeships and urging legislators to continue this trend).

114. Federal judges, including Chief Justice Rehnquist, also have been critical of the Civil Justice Reform Act of 1990, Pub. L. No. 101-650, 104 Stat. 5089. By regulating the ways district courts develop procedures for managing their dockets, the Judicial Conference saw the Act as both "subjecting court rules to political whimsy" and violating "the separation of powers doctrine by having the legislature manage the workings of the courts." Stephen Labaton, Business and the Law, Biden's Challenge to Federal Courts, N.Y. TIMES, Apr. 16, 1990, at D2; see also 
claims about what is in the best interest of the judicial branch may “obscure the judges' self-interested personal motivations for preserving and enhancing their own positions in the system," ertheless true that the Supreme Court has ample reason to point the finger at Congress for changing (for the worse) the job of being a federal court judge. It is hardly surprising that this change has occurred during the same period that the Court increasingly has struck down acts of Congress. The Court's view of Congress is shaped, in part, by Congress's interest in addressing matters that the judiciary deems essential to the administration of justice. ${ }^{116}$

\section{CONCLUSION: WAKE ME UP WHEN THE REVOLUTION IS OVER}

In determining what deference is owed to Congress, the Justices cannot help but think about how seriously Congress takes both the Constitution and the Court. ${ }^{117}$ For this reason, Congress is partially to blame for the recent wave of Court decisions invalidating federal laws. Poor drafting, including inattention to the signals being sent to Congress by the Supreme Court, has figured prominently in this raft of decisions. Likewise, Congress's apparent disinterest in preserving its power as a coequal interpreter of the Constitution encourages the Court to see itself as the ultimate arbiter of constitutional truth. And finally, Congress's "what-me-worry" attitude toward judicial branch needs has exacerbated strains between the Court and Congress.

Rehnquist, supra note 92, at 3B (criticizing the Act for "lessening the traditional freedom of the district judge").

115. Christopher E. SMith, Judicial Self-InTEREst: Federal Judges AND Court Administration 133 (1995); see also Neil A. Lewis, Hatch Defends Senate Action on Judgeships, N.Y. TIMES, Jan. 2, 1998, at A1 (suggesting that judges were "partly to blame for their heavy caseloads"). See generally Charles Gardner Geyh, Paradise Lost, Paradigm Found: Redefining the Judiciary's Imperiled Role in Congress, 71 N.Y.U. L. REV. 1165, 1224-29 (1996) (discussing possible methods of facilitating positive interaction between Congress and the courts).

116. Of course, the Justices' principal concern is the statute the constitutionality of which is being challenged. Nevertheless, judicial attitudes toward Congress are likely to be a contributing factor in defining the Court's views on Congress's trustworthiness and, with it, the Court's willingness to take a hard look at Congress's handiwork. See supra note 97 and accompanying text (noting the correlation between congressional actions and Supreme Court decisionmaking).

117. Professor Schroeder, therefore, is correct in calling attention to how "motivated reasoning" affects Court decisionmaking. See Schroeder, supra note 4, at 352-56 (reasoning that general distrust of the federal government provides Justices with a reason to prefer limiting federal power). Just as the Justices (perhaps subconsciously) factor attitudes toward Congress's trustworthiness into their decisionmaking, the Justices also are apt to take into account Congress's views about its role in constitutional interpretation. 
That Congress is partially to blame for bringing back the "Constitution in Exile" cannot be denied. The Rehnquist Court, already predisposed to pay close attention to issues involving the scope of Congress's power, has seized upon Congress's failure to take seriously its role as coequal interpreter of the Constitution. But why is Congress increasingly cavalier in its handling of constitutional questions? To begin with, lawmakers have little incentive to sacrifice their individual interests for something as abstract as Congress's institutional interest in asserting its voice as coequal interpreter of the Constitution. ${ }^{118}$ In particular, members of Congress need to be reelected to advance their (and their constituents') interests. With little to gain by raising constitutional objections to a politically popular bill, lawmakers would rather vote for the measure and leave it to the courts to sort out the bill's constitutionality. ${ }^{119}$ Nothing, of course, is new about this practice; nevertheless, several recent developments have conspired to make Congress especially insensitive to the constitutional fate of its enactments.

First, Congress not only increasingly delegates its core powers to others, but also, in explaining why, it often points the finger at itself for the failings of government. Witness, for example, the 1994 Contract with America. Premised on the belief that Congress is irresponsible and unworthy of trust, the Contract with America ostensibly sought to limit congressional power in several ways, including by imposing term limits, prohibiting unfunded mandates, and creating the line-item veto. On the line-item veto, for example, Senator Dan Coats and others argued: Congress "cannot discipline itself. ... [It] is selfish and greedy and ... cannot put the national interest ahead of parochial interests or special interests." ${ }^{120}$ And while the Contract with America

118. Lawmakers, in other words, are "trapped in a prisoners' dilemma: all might benefit if they could cooperate in defending or advancing Congress's power, but each has a strong incentive to free ride in favor of the local constituency." Terry M. Moe \& William G. Howell, The Presidential Power of Unilateral Action, 15 J.L. ECON. \& ORG. 132, 144 (1999).

119. This, in part, explains both the use of expedited review provisions, see supra notes 3144 and accompanying text, and the paucity of lawmaker references to recent Supreme Court decisions striking down acts of Congress, see supra notes 76-83 and accompanying text. For a competing perspective, see Elizabeth Garrett \& Adrian Vermeule, Institutional Design of a Thayerian Congress, 50 DUKE L.J. 1277, 1288 (2001) ("[S]ome legislators sometimes treat constitutional argument as one indicator of the 'public interest' or 'good public policy,' which in turn has some weight as against legislators' other interests, goals, and aims.").

120. Line-Item Veto: Joint Hearing Before the House Comm. on Government Reform and Oversight and the S. Comm. on Governmental Affairs, 104th Cong. 22 (1995) (quoting Sen. Coats (R-IN)). Moreover, Senator Gordon Humphrey observed: "Congress has flunked the test. We do not deserve the status quo. We have flunked. We are dunces, we are truants, we are 
has fizzled, Congress remains ready, willing, and eager to cede core powers-especially budgetary and war powers. ${ }^{121}$ This pattern is likely to continue, for the declining public trust in government creates incentives for lawmakers to distance themselves from Congress by engaging in mutual self-flagellation. ${ }^{122}$

Second, Congress has little incentive to take recent Supreme Court decisions into account and thereby slow down the pace of federalization because interest groups increasingly prefer national legislation to state and local measures. ${ }^{123}$ As compared to lobbying fifty state legislatures, for example, there is a far lower transaction cost associated with national legislation. ${ }^{124}$ More significantly, the political culture has become increasingly nationalized. Changes both in media coverage and advertising have made all politics national-so that guns in schools, carjacking, and the like are considered national, not local, problems.

Third (and relatedly), Congress is not particularly disappointed with Court decisionmaking. Unlike during Court-curbing periods, many members of Congress now are somewhat sympathetic to, say,

juvenile delinquents with the budget.” 135 CONG. REC. 28,091 (1989) (statement of Sen. Humphrey (R-NH)). Needless to say, term limits take aim at Congress in an even more direct way. Representative Henry Hyde noted: "The popularity of term limits is a measure of the low esteem our citizens have for politics and politicians.... [And given the way we] attack each other and the way we demean this institution in every campaign, it is no wonder we are held in contempt." 143 CONG. REC. H470 (daily ed. Feb. 12, 1997) (statement of Rep. Hyde (R-IL)).

121. For a detailing of the steady and continuing decline of Congress's war and spending powers, see generally FISHER, CONGRESSIONAL ABDICATION, supra note 29.

122. See Schroeder, supra note 4, at 347 (providing a graph gauging the rise and fall of public trust in government from 1958-1998).

123. See generally Barry Friedman, Valuing Federalism, 82 MINN. L. REV. 317, 364-78 (1997) (describing the centripetal forces that account for the tendency toward centralization of regulatory authority); Marshall, supra note 106, at 141-47 (discussing Congress's reaction to the Supreme Court's revived concern for federalism).

124. See Friedman, supra note 123, at 373-75 (explaining the economic benefits for interest groups in seeking federal, rather than state, regulation); see also Jonathan Macey, Federal Deference to Local Regulators and the Economic Theory of Regulation: Toward a Public-Choice Explanation of Federalism, 76 VA. L. REV. 265, 272-73 (1990) (calling attention to the fact that it is harder for regulated parties to avoid national, as compared to local, regulation).

125. See Marshall, supra note 106, at 151-52 (reasoning that media coverage of distant crimes creates the impression that crime requires a national solution). Correspondingly, there is little cost to Congress if the Supreme Court invalidates its statutes. In particular, by enacting the statute, lawmakers accomplish their principal objective, that is, signaling to relevant constituents that they are working on the problem. See infra notes 130-33 and accompanying text (discussing the rise of symbolic legislation). Moreover, Congress, if need be, can respond to the Supreme Court by enacting a narrower version of the bill. See supra note 58 and accompanying text (discussing examples). 
Court efforts to protect state prerogatives. ${ }^{126}$ For this very reason, Representative Lee Hamilton, after observing that lawmakers seemed "detached from the actual work of the federal judiciary, particularly as it relates to the exercise of congressional power," speculated that Congress "has become more conservative, and many members are comfortable with most of the Court's rulings." ${ }^{127}$ Moreover, Supreme Court decisions have not prevented Congress from responding to constituent demands. Congress has the tools to respond to many of these decisions. For example, it can recraft a bill by grounding it in a different source of federal power or it can narrow its scope. ${ }^{128}$ Finally, because much of what is struck down is redundant of state enactments, Congress will feel relatively little constituent pressure to respond to the Court. ${ }^{129}$

Fourth, Congress increasingly is concerned with "message politics," that is, using the legislative process to make a symbolic statement to voters and other constituents. ${ }^{130}$ Rather than look to commit-

126. When Court decisionmaking has upset the constituencies of individual members of Congress (for example, in the case of court-ordered busing or the rejection of early New Deal legislation), Congress had a reason to defend its institutional prerogatives and pressure the Court to follow Congress's understanding of the Constitution. When Congress is not at war with the Court, however, the individual interests of its members diverge from the institutional interest of defending Congress's constitutional power as coequal interpreter of the Constitution. See supra notes 29-30 and accompanying text (detailing why Congress-when it comes to interpreting the Constitution - has little incentive to fight for its institutional prerogatives).

127. 144 CONG. REC. E48 (daily ed. Jan. 28, 1998) (statement of Rep. Hamilton (D-IN)).

128. See Gerhardt, supra note 85, at 10988-90 (explaining how Congress can make better use of its treaty and spending powers); see also T.R. Goldman, Lawmakers Take Steps to Respond After Legislation Is Found Unconstitutional, LEGAL TIMES, July 14, 1997, at 8 (arguing that Congress can enact more comprehensive regulatory schemes than those struck down by the Court); Adrian Vermeule, Does Commerce Clause Review Have Perverse Effects? 1-5 (Oct. $28,2000)$ (unpublished manuscript, prepared for "New Voices on the New Federalism," Villanova Law School, Oct. 28, 2000) (on file with the Duke Law Journal) (same); supra note 58 and accompanying text (discussing examples of congressional responses); infra note 138 and accompanying text (discussing how the Court benefits from such an incremental strategy).

129. See infra notes 130-133 and accompanying text (discussing how Congress seems especially interested in approving symbolic legislation). Furthermore, were the Supreme Court to shut the door on federal initiatives, constituents still could seek relief from state lawmakers. Following the Supreme Court's rejection of Congress's efforts to extend the Americans with Disabilities Act to state agencies, for example, several states passed legislation waiving their immunity to federal ADA lawsuits. See Helen Irvin, Several States Respond to Garrett Decision, Consider Waiving Immunity to ADA Lawsuits, 70 U.S.L.W. 2003 (2001) (discussing bills recently introduced in Minnesota, Rhode Island, California, and New York).

130. See generally C. Lawrence Evans, Message Politics: Party Campaigning and Legislative Strategy in Congress (Aug. 2000) (paper presented at the Annual Meeting of the American Political Science Association) (unpublished manuscript, on file with the Duke Law Journal) (ar- 
tee leadership to define Congress's agenda, Republicans and Democrats alike see the lawmaking process as expressive, a way for the members of each party to coalesce behind their party's policy agenda. ${ }^{131}$ Likewise, by focusing its efforts on the message it is sending, Congress places less emphasis on what happens to legislation after it is enacted. Instead of negotiating with the president over the specifics of legislation (so as to stave off a possible veto), "Congress can, and routinely does, pass laws deliberately designed to provoke a presidential veto." ${ }^{, 132}$ Likewise, a Court decision striking down legislation is not especially problematic. Indeed, the Court's decision creates an occasion for Congress to revisit the issue and, in this way, facilitates lawmaker efforts to, once again, send a symbolic message to voters and other constituents. ${ }^{133}$

Congress has yet to see the return of the "Constitution in Exile" as especially problematic. The changing face of lawmaking places less emphasis on securing presidential and judicial approval of legislation and more emphasis on doing what is politically popular (federalizing crime, for example). So long as the Court is not standing in the way of urgent constituent demands, there is little reason for Congress to break out of this pattern. In other words, the constitutional counterrevolution that so preoccupies legal academics appears little more than a blip on Congress's radar screen.

For the Rehnquist Court, however, Congress's apparent indifference to its rulings is anything but insignificant. The Court waited until the 1994 elections before launching its counterrevolution, and even then the Court moved gingerly-striking down relatively few laws and striking them down on somewhat ambiguous grounds. ${ }^{134}$ Today,

guing that "message politics" shapes the strategic decisions of legislators at all stages of the lawmaking process).

131. Id. at 3 .

132. See John B. Gilmour, Institutional and Individual Influences on the President's Veto, J. PoL. (forthcoming) (manuscript at 5, on file with the Duke Law Journal).

133. And with voters expecting less and less of Congress, it may be that this type of signal satisfies lawmakers' needs to get something done (that they can report back to their constituents). See Schroeder, supra note 4, at 336-38 (detailing voters' lower expectations for congressional performance).

134. Most notably, following the Court's decision in United States v. Lopez, 514 U.S. 549 (1995), there was reason to think that the Court's sole complaint with the guns-near-schools laws was the paucity of legislative factfinding. See Philip Frickey, The Fool on the Hill: Congressional Findings, Constitutional Adjudication, and United States v. Lopez, 46 CASE W. RES. L. REV. 695, 703 (1996) (contrasting the Fifth Circuit's focus on the absence of findings with the Supreme Court's concession that their absence simply negated one source of support); see also 
however, the Court seems more aggressive, and with good reason. Congress, if anything, is encouraging the Court through both indifference and ill-considered legislation. Moreover, there is little reason to fear a populist backlash like the one launched against Lochner-era judicial decisionmaking. ${ }^{135}$ The Court remains politically popular ${ }^{136}$ and somewhat middle-of-the-road on divisive social policy issues such as late-term abortions and school prayer. ${ }^{137}$ Also, when the Court strikes down a law, it typically leaves Congress room to revisit the issue. ${ }^{138}$

Of course, it is not impossible that the Court's increased willingness to invalidate Congress's statutes will become a politically salient issue-one that spurs Congress into action. ${ }^{139}$ As the New Deal

Whittington, supra note 95, at 479 (arguing that the "Court has moved carefully but steadily to reestablish some federalism-based constraints on the national government").

135. See supra note 24 and accompanying text (noting that popular opinion, in part, animated the 1937 revolution). "Lochner-era" refers, of course, to the years following the Court's decision in Lochner v. New York, 198 U.S. 45, 64 (1905), invalidating a New York labor law as violative of an employee's Fourteenth Amendment right to freedom of contract.

136. In his 1999 year-end report, for example, Chief Justice Rehnquist approvingly cited a February 1999 Gallup Poll showing that " 80 percent of Americans surveyed stated that they had a 'great deal' or 'fair' amount of trust in the judicial branch of government, far exceeding figures for the other branches." Rehnquist, supra note 110. For the Supreme Court, 81 percent of Americans, in a June 2001 Gallup Poll, said they have "some," "quite a lot," or a "great deal" of confidence in the Supreme Court. Confidence in Institutions, Gallup.com, at http://www.gallup. com/poll/indicators/indconfidence.asp\#RelatedAnalyses (June 8-10, 2001) (on file with the Duke Law Journal). In other words, the Supreme Court does not appear to have suffered much harm for its participation in Bush v. Gore, 531 U.S. 98 (2000). See also Wendy W. Simmons, Election Controversy Apparently Drove Partisan Wedge into Attitudes Towards Supreme Court, Gallup.com, at http://www.gallup.com/poll/releases/pr010116.asp (Jan. 16, 2001) (on file with the Duke Law Journal) (noting that, in its immediate aftermath, Bush v. Gore affected Democratic and Republican attitudes toward the Court).

137. For assessments of the 2001 Term (all of which suggest that the Court, rather than being hard-line, was difficult to pigeonhole), see Alan M. Dershowitz, Curious Fallout from Bush v. Gore, N.Y. TIMES, July 4, 2001, at A15; Richard W. Garnett, Disrobed! Actually, They Think for Themselves, WASH. Post, July 1, 2001, at B2; Greenhouse, supra note 1, at A1. On the question of whether the Lochner-era Court preserved political capital by strategically packaging its decisions, see Gregory A. Caldeira, Public Opinion and the U.S. Supreme Court: FDR's CourtPacking Plan, 81 AM. POL. SCI. REV. 1139, 1139 (1987) (arguing that the Court was hugely successful in "shap[ing] events and build[ing] up institutional support with a series of well-timed decisions").

138. See supra note 58 and accompanying text; see also Barry Friedman, Legislative Findings and Judicial Signals: A Positive Political Reading of United States v. Lopez, 46 CASE W. RES. L. REV. 757, 776-79 (1996) (employing positive political theory to argue that, after declaring a statute unconstitutional, the Court encourages an equilibrium among the branches by leaving the door open for Congress to revisit its handiwork).

139. Furthermore, the Court itself is an issue-but not because of its anti-Congress decisionmaking. Concerned with abortion, civil rights, and civil liberties, the Senate Judiciary Com- 
Court's exiling of the Lochner-era decisionmaking suggests, the Justices can make the Court a political issue by frustrating a broad populist mandate. ${ }^{140}$ For example, if the face of Congress changes, it is possible that the Court may find itself out-of-step with the policy preferences of lawmakers. Indeed, because Democrats now control the confirmation of federal court appointees, lawmakers-interested in limiting the George W. Bush administration's power to shape federal court decisionmaking-may try to make the Court an issue. Also, the Justices' growing confidence in their anti-Congress agenda (especially if fueled by Bush appointees willing to push the envelope even further) may result in rulings that prod Congress into action. ${ }^{141}$ Until that time, however, Congress is likely to sit back and wait out the purported return of the "Constitution in Exile." Its motto (if it had the energy to have one): "Wake Me Up When the Revolution is Over."

mittee is now engaged in a battle over what role, if any, ideology should play in the selection and confirmation of judges. See Charles E. Schumer, Judging by Ideology, N.Y. TIMES, June 26, 2001, at A19 (arguing that senators should use ideology when examining judicial nominees); Byron York, More Hearings, More Delays, NATIONAl ReVIEw OnLINE, at http://www. nationalreview.com/york/york062601.shtml (June 26, 2001) (on file with the Duke Law Journal) (same); Meet the Press: Senators Charles Schumer and Jeff Sessions Discuss Whether Personal Ideology Should Matter When Confirming Federal Judiciary Nominees (NBC television broadcast, July 1, 2001) (transcript on file with the Duke Law Journal) (same).

140. See Caldeira, supra note 137, at 1143-44 (discussing the relationship between media coverage of the Supreme Court and support for Court-packing); Richard Funston, The Supreme Court and Critical Elections, 69 AM. POL. SCI. REV. 795, 802 (1975) (noting the decline and subsequent rise in Court prestige after the Civil War and its impact on judicial ability to direct public policy).

141. Following the Sept. 11, 2001, terrorist attacks on the World Trade Center in New York and on the Pentagon, it is possible that the Justices will slow down their efforts to limit Congress. In particular, social and political forces may dictate that the Court pay greater respect to the federal government. Linda Greenhouse, Will the Court Reassert National Authority?, N.Y. TIMES, Sept. 30, 2001, at 4. With that said, there is little reason to think that the Court will disavow its recent decisions limiting Congress's power. It seems more likely that the Court will steer away from these disputes (at least in the near future) by making use of certiorari denials and other delaying strategies. Also, on questions that have no direct relationship to national security, it is possible-albeit less likely now than before-that the Court will continue to limit Congress's power. 